University of Nebraska - Lincoln

DigitalCommons@University of Nebraska - Lincoln

USDA National Wildlife Research Center - Staff Publications
U.S. Department of Agriculture: Animal and Plant Health Inspection Service

2020

\title{
Control or eradication: Problems in the management of invasive birds
}

\author{
Michael L. Avery \\ USDA APHIS Wildlife Services, gibs8387@gmail.com \\ Chris J. Feare \\ WildWings Bird Management, Haslemere, Surrey, UK
}

Follow this and additional works at: https://digitalcommons.unl.edu/icwdm_usdanwrc

Part of the Natural Resources and Conservation Commons, Natural Resources Management and Policy Commons, Other Environmental Sciences Commons, Other Veterinary Medicine Commons, Population Biology Commons, Terrestrial and Aquatic Ecology Commons, Veterinary Infectious Diseases Commons, Veterinary Microbiology and Immunobiology Commons, Veterinary Preventive Medicine, Epidemiology, and Public Health Commons, and the Zoology Commons

Avery, Michael L. and Feare, Chris J., "Control or eradication: Problems in the management of invasive birds" (2020). USDA National Wildlife Research Center - Staff Publications. 2389.

https://digitalcommons.unl.edu/icwdm_usdanwrc/2389

This Article is brought to you for free and open access by the U.S. Department of Agriculture: Animal and Plant Health Inspection Service at DigitalCommons@University of Nebraska - Lincoln. It has been accepted for inclusion in USDA National Wildlife Research Center - Staff Publications by an authorized administrator of DigitalCommons@University of Nebraska - Lincoln. 
Control or eradication: problems in the management of invasive birds

\author{
Michael L. Avery ${ }^{1 *}$ and Chris J. Feare ${ }^{2}$ \\ 1 USDA National Wildlife Research Center; Gainesville, FL 32641, USA; \\ ${ }^{2}$ WildWings Bird Management, Haslemere, Surrey, UK
}

\begin{abstract}
Citation: Avery, M.L. and Feare, C.J. (2020) Control or eradication: problems in the management of invasive birds. In: Downs, C.T. and Hart, L.A. (eds) Invasive Birds: Global Trends and Impacts. CAB International, Wallingford, UK, pp. 349-361.
\end{abstract}

\subsection{Introduction}

Humans have captured, transported and intentionally released wild birds for centuries (Blackburn et al., 2009). Motivations for such purposeful introductions include food (West and Zhou, 2007), religion (Agoramoorthy and Hsu, 2007), sport (McDowall, 1994), biocontrol (Bennett and Hughes, 1959; Kurdila, 1995) and aesthetics (Ryan, 1906; Thomson, 1922). Many purposeful bird introductions were the work of acclimatization societies, particularly in North America, New Zealand and Australia. These societies were formed in the 19th century by European settlers to transport bird species from their homelands in efforts to establish them in the newly settled regions (Thomson, 1922; Dunlap, 1997). As a result of these efforts, the Common or European Starling (Sturnus vulgaris), the House Sparrow (Passer domesticus) and many other species are now permanently established far beyond their native ranges.

Commercial trade in captive birds is also an important introduction pathway. Non-native species are introduced through unintentional releases of cage birds and inadvertent escapes from research facilities, zoos and private collections. The international bird trade has declined gradually following adoption in the USA of the 1992 Wild Bird Conservation Act and similar European regulations restricting trade in wild birds following the westward spread from China of the highly pathogenic $\mathrm{H} 5 \mathrm{~N} 1$ avian influenza virus in the early 2000s (Cooney and Jepson, 2006). The pattern of trade in wild birds has also changed. Mexico and Asia have replaced the USA and the European Union as the principal importers in the global cage-bird market (Cardador et al., 2017; Hobson et al., 2017). Nevertheless, large-scale traffic in wild and captive-bred birds continues. During the 3-year period 2000-2002, global exports of live birds totalled $3,640,135$ compared with 807,476 during 2015-2017 according to the Convention on International Trade in Endangered Species (CITES, 2018).

Invasive birds have major impacts throughout the world, regardless of the invasion pathway. Pimentel et al. (2001) examined the published data available on invasive species in the USA, the UK, Australia, South Africa, India and Brazill. They concluded that introduced birds were responsible for US\$2.4 billion in damage to agriculture, human health and natural resources among these six countries.

We focus in this chapter on a subset of these impacts, namely the threats that invasive birds pose to native species and the efforts that have been made to reduce or eradicate such impacts. Specifically, we review management options and control strategies, explore what has and has not been effective, and discuss case histories of success and failure.

\subsection{Management Options}

Invasive species management can be viewed as a process occurring along a time continuum on which management costs and difficulty increase with time. Following a scheme developed and articulated for Australian agricultural resources (Department of Primary Industries, 2010), Harvey and Mazzotti (2014) defined four stages within the invasive species management process: prevention, eradication, containment and long-term management.

\subsubsection{Prevention}

By far, prevention yields the greatest management benefit per unit cost. Prevention obviates the need for subsequent

*Corresponding author (retired): gibs8387@gmail.com 
management because the invasive species does not become established in the first place. Prevention procedures must be applied throughout the importation/transportation process to minimize inadvertent releases en route or at the destination port of entry. Unfortunately, prevention strategies can fail either because they are poorly conceived or because they are not implemented properly. There are now more than 200 bird species occupying areas beyond their native ranges, and at least 36 of these have some level of ecological impact, including competition, predation, hybridization and disease transmission with native taxa (Lever, 2005; Martin-Albarracin et al., 2015).

\subsubsection{Eradication}

When a species evades the prevention phase and invades non-native space, eradication should become the primary goal. Unfortunately, eradication is not always realistic. There is, in most cases, a relatively short window, while the invasive population is small and localized, when eradication is a realistic management objective. However, if such opportunities are not seized, the prospects for eradication diminish rapidly. Eradication goes together with a policy of early detection and rapid response (EDRR). The sooner a management response can be mounted and implemented, the greater the chance of stopping the invasion before it gets out of hand. Feasibility and cost of eradication vary with the size of the population and the size of the geographical area occupied by that population. Both of these parameters can be related to time since introduction, with founder populations predicted to be smaller and more localized than established populations.

EDRR is costlier than prevention, but, in most cases, it represents the last chance for eradication. The effectiveness of an EDRR effort can be enhanced by ongoing monitoring, research into species' life histories and impacts, and development of detection and removal tools. An EDRR strategy offers opportunities for public participation in learning how to identify, detect and report invaders.

Management based on EDRR is especially warranted when there is high probability that the invasive species will cause serious impacts and, if unchecked, is likely to reproduce and disperse, thus compounding the difficulties for successful control (Simberloff, 2003). Several conditions favour a successful EDRR strategy:

1. Public support. Natural resource managers ideally will have foreseen the benefit of a public well-informed about invasive species, and they will have established the need for an EDRR programme supported by the public. Education and outreach are important components of such an approach and are invaluable in implementing an EDRR programme to address invasive species concerns (Temple, 1992). In some cases, active participation by the public has been essential to the eradication success (e.g. Suleiman and Taleb, 2010).

2. Resources. Early detection of an incipient invasion is of little value unless properly trained personnel with adequate logistical support are available to respond promptly. Public support of an EDRR programme for invasive species management implies that personnel, equipment and funds for conducting the necessary field activities have been allocated. An effective rapid response will prevent the invasive front from advancing and dispersing, and will increase likelihood of success. The rapid response will also lessen the time that the presence of the invasive species can be publicized and attract avid birders interested in adding an unusual sighting to their records. Unless resources are already allocated and available, timely responses to reports of invasives cannot be guaranteed.

3. Regulations. An efficient, rapid response to an invasive bird species will be greatly facilitated if regulatory procedures (e.g. permits, access to properties) are well understood and anticipated. Management actions will proceed more smoothly if the EDRR responders maintain regular contact with the relevant oversight agencies or departments so that action plans and response strategies can be discussed and agreed prior to any urgent need. Potential permitting issues related to the use of lethal control (firearms, toxicants) or animal welfare concerns should be resolved in up-front discussions with appropriate authorities.

\subsubsection{Containment}

If immediate action is not taken, or if the initial response is inadequate, invasive species will reproduce and spread through suitable habitats. Eradication becomes increasingly unlikely as the species increases in number and invades new areas. When populations become established, management efforts shift from eradication to controlling the spread of a species. Intense efforts are necessary to contain the core population of a species and extirpate it from new areas.

\subsubsection{Resource protection and long-term management}

When an invader is too widespread and abundant to control everywhere it occurs, eradication becomes impossible. Longterm management aims to reduce populations to the lowest feasible levels and to protect specific highly valued resources. Community support can be critical to ensure the success of long-term management programmes because such efforts could require sustained funding and staffing across many years.

\subsection{Eradication or Control?}

'Eradication is an intense, time-limited process offering perpetual freedom from the pest, its effects, and control costs. By contrast, continuing control is a recurrent activity with continuing damage and control costs' (Bomford and O'Brien, 1995). When the existence of an endangered species or other highly valued natural resource is threatened by an invasive species, managers will probably opt for eradication of the invasive population (Feare, 2010a). Eradication offers maximum, long-term protection for native fauna and flora, but practicality, cost and public acceptability affect the likelihood that eradication can be achieved. The feasibility and 
cost of eradication vary with the size of the population and the size of the geographical area occupied by that population. The techniques available for eradication can be limited by potential side-effects on native fauna and flora, and the effectiveness of techniques can vary among species of invasive birds, and even among different populations of the same species.

The biota on many islands is threatened or endangered, and there have been numerous eradication efforts to rid islands of invasive wildlife (e.g. rodents, Howald et al., 2007; feral goats, Campbell and Donlan, 2005; feral cats and rabbits, Robinson and Copson, 2014). Non-native bird introductions are greatly biased towards islands (Blackburn et al., 2009), but compared with mammals, eradication efforts seldom target invasive birds. Glen et al. (2013) reviewed 1068 vertebrate eradications on 749 islands worldwide. Of the successful vertebrate eradications, $1043(98 \%)$ were of mammals; only 24 eradications targeted invasive birds.

Regardless of taxon, eradication of an invasive continental population is rare. Fleming et al. (2017) noted that no established invasive vertebrate or plant has been eradicated from a continent. Bomford and O'Brien (1995) proposed the following criteria for successful eradication of an invasive wildlife population:

- The rate of removal must be greater than reproductive rate at all population densities.

- Immigration must be zero.

- All reproductive animals must be at risk of control tools and strategies.

- The target species are able to be monitored at low densities.

- The discounted cost-benefit analysis favours eradication over ongoing suppression.

- The socio-political environment is suitable.

The first three are 'essential' criteria without which eradication cannot succeed. The remaining three are 'desirable' and must be met for eradication to be the preferred management option. These six criteria are rarely ever met in mainland invasive populations.

We suggest that there have been eradications of invasive bird populations from mainland areas, such as the Sacred Ibis (Threskiornis aethiopicus) in Barcelona (Clergeau and Yésou, 2006) and the American Black Duck (Anas rupripes) in British Columbia (Fenneman, 2011), but they do not occur often and always involve small, localized populations. Thus, for most mainland invasive bird populations, particularly those that are decades old, eradication could be unrealistic. If such conditions pertain, then maintaining the population at a given level through long-term management might be an acceptable option. Long-term management is not necessarily an admission of defeat but rather should be viewed as one alternative in addressing a difficult problem (Simberloff, 2009).

\subsection{Control Methods}

Some wild bird populations negatively impact human health and safety through agricultural losses, zoonotic disease transmission, property damage and other factors. In response, numerous commercial devices and chemicals have been developed in attempts to alleviate these impacts. Many of the commonly used bird damage control methods are non-lethal and probably have little utility in strategies to reduce or eliminate populations of invasive birds.

When eradication is the management objective, three basic types of lethal control measures are employed: (i) live trapping, followed by relocation or humane euthanasia; (ii) selective shooting; and (iii) applying toxic bait. Each of these approaches requires training and experience to implement safely and effectively.

\subsubsection{Trapping}

Numerous types of live traps are available to wildlife managers. The target species will determine the design and deployment of the live traps to address a given situation. Large drop nets can be used effectively to capture groups of ground-foraging birds such as Wild Turkeys (Meleagris gallopavo; Morrison et al. 2016). Corvids and other highly social species are susceptible to capture in large, baited, drop-in pen traps (e.g. Tsachalidis et al., 2006). Trap success can usually be improved by maintaining two or three birds of the target species within the trap to attract conspecifics. A dripping water source inside the pen will also attract outside birds, as well as provide those already caught with drinking and bathing water. Various designs of smaller live traps with decoy birds have been employed successfully in campaigns to control Common Mynas(Acridotheres tristis; Tidemann, 2005; Saavedra, 2010; Canning, 2011).

Removing nestlings and eggs from nests of invasive species can augment the lethal control measures targeting the adult birds. Eradication of the House Crow (Corvus splendens) from Socotra, Yemen, was attributed in part to the successful efforts of school children locating nests, removing the contents and bringing the young crows to authorities to be euthanized (Suleiman and Taleb, 2010). Destruction of nests, eggs and nestlings has also contributed, albeit in a minor way, to eradication of an island myna population (Canning, 2011).

A period of pre-baiting is recommended for most trapping programmes to overcome neophobia and to create a seemingly benign, or even attractive, environment for the target animals. Pre-baiting entails setting up the trap, providing bait and then allowing target animals to come and go freely. The trap is set or activated when observations confirm reliable visitation by the target species. Trapping proceeds until the capture rate diminishes to an unacceptable level. A different site might then be established, or a new method employed.

In most cases, trapped birds will be humanely dispatched following applicable guidelines as designated by the appropriate local authorities (e.g. American Veterinary Medical Association, 2001). Euthanized birds can be sources of otherwise unobtainable information on the target species, and the specimens should be used to the greatest extent possible to increase understanding of the invasive species (Feare, 2010a).

\subsubsection{Shooting}

A carefully planned and expertly executed shooting campaign can prove invaluable in an eradication programme (e.g. 
Suleiman and Taleb, 2010; Morrison et al., 2016). Daily feeding sites, water holes, roosts and other places where target birds reliably congregate are often ideal shooting locations, but regular shooting at such sites can instil location avoidance. For eradication of invasive species, use of expert marksmen with understanding of the behaviour of the target species is encouraged. Shooting is frequently essential for removing the final few trapor bait-shy individuals.

Statutes and regulations governing possession and use of firearms vary geographically, so it is vital that the appropriate authorities be consulted and the necessary permits obtained in advance.

\subsubsection{Toxicants}

Starlicide (3-chloro- $p$-toluidine hydrochloride, also known as DRC-1339) was developed over 50 years ago and has been used ever since in management of pest populations of European starlings and other problem bird species in the USA (DeCino et al., 1966; Eisemann et al., 2003). Common Mynas are very sensitive to this toxicant (Avery and Eisemann, 2015). It has been used in myna control programmes on several islands with varying degrees of success (Millett et al., 2004; Feare, 2010b; Parkes, 2012). Deployment of toxic bait might have most utility to reduce a large population of invasive birds quickly so that trapping and shooting can then be efficiently employed (Millett et al., 2004; Parkes, 2012). Population reduction with toxic bait is best viewed as a first step and should be followed promptly by determined application using other techniques to achieve the goal of eradication. This approach was used successfully in the Cook Islands (see section 43.5.2) and might be applicable in other invasive bird management situations.

Advance planning is crucial for a successful toxic baiting programme. Potential bait sites, types of bait, schedule, amount of bait deployed and possible non-target species are among the factors to be considered. Use of Starlicide, or any toxicant, in the vicinity of endangered endemics (all taxa, not just birds) will be problematic because potential impacts on other organisms such as insects, crustaceans, amphibians, reptiles and fish are poorly studied, so extreme caution is needed.

Most birds ingesting Starlicide bait do not die at the bait site, and the numbers of birds killed will be difficult to determine. Furthermore, a day-to-day lessening in visitation rates to bait sites could reflect feeding site aversion, not simply mortality in the target population.

Candidate bait sites should be provisioned with untreated baits and monitored for several days to document use by the target species and any non-target animals. This pre-baiting period should establish a feeding pattern among the local target birds. The observations will enable personnel to determine the best time of day and duration for baiting, and the optimal quantity of treated bait to deploy at the site to maximize exposure to the target species and minimize the potential risk to non-targets. Starlicide bait should be formulated to deliver a lethal dose to the target species in a single bait (Glahn and Avery, 2001). In field applications, the treated baits are mixed with untreated baits (e.g. 20:1 or 30:1, untreated:treated). This ensures that not every bird ingests lethal bait on the first day. Thus, a portion of the feeding flock will return to the bait site on subsequent days, recruiting new birds each time until maximum effect is achieved. In an ideal baiting programme, the amount of bait offered will be depleted by the target birds during their initial daily morning feeding bout, leaving nothing at the bait site for non-targets to ingest. If there is any doubt about treated bait remaining after a presentation, it should be offered in such a way that any remaining bait can be collected and destroyed.

\subsubsection{Integrated management}

An eradication strategy that succeeds in one situation will not necessarily be as effective under different conditions, even if the same target species is involved. Three myna eradications in the Seychelles revealed unexpected differences in the responses of Common Mynas to trap types. On Frégate Island, Canning (2011) caught $97 \%$ of the 745 mynas killed in commercially made Mini Myna traps (funnel traps that permit multiple birds to be caught: http://mynamagnet.com.au/, accessed 15 November 2019). On Denis Island, these traps were inefficient, accounting for only $0.9 \%$ of 1090 mynas captured, whereas decoy traps (cage traps that contain a live myna decoy in a central compartment surrounded by four single-catch compartments) were much more effective (Feare et al., 2016). On North Island, 226 out of 1538 mynas $(14.7 \%)$ were caught in Mini Myna traps, with most of the remainder being caught in decoy traps. The efficiency of Mini Myna traps on North Island appeared to be related to habitat and the associated density of feeding birds. On managed grassland, which represented the most widespread habitat used by mynas on the island, mynas were readily caught in decoy traps but not in Mini Myna traps, whereas at a site where the dumping of organic waste each morning attracted large numbers, Mini Myna traps were much more successful. A similar association between habitat type and relative trap success was found during a feasibility study of controlling Common Mynas on St Helena Island (Feare and Saavedra, 2009).

Each management situation has its own set of peculiarities that will influence the optimal course of action. Each lethal technique has advantages and disadvantages, and none is a magic bullet. It would be very unusual for an eradication programme to succeed relying on a single method. More likely, a successful programme will employ several methods, lethal and non-lethal, in an integrated effort to address a given invasive species problem (Feare, 2010a). Sometimes, a trial-anderror approach will be needed; in other cases, eradication efforts can be guided by the successes of others under similar conditions. Parkes (2012) reviewed several control programmes targeting the Common Myna and concluded that the most effective approach was sequential application of poisoning, trapping and shooting.

The recommendation of Parkes (2012) for the Common Myna might be an appropriate starting point for devising an eradication programme, but there is no prescription that will fit all situations. Numerous factors will impinge on the feasibility 
of carrying out a successful eradication programme, including environmental (e.g. weather, terrain), ecological (e.g. non-targets, natural history of target species), economic (e.g. equipment, personnel), governmental (e.g. permits, access to property) and human (e.g. public support, availability of volunteers). In populated areas, the human dimension is possibly the most challenging set of factors (e.g. Phillips et al., 2012). Glen et al. (2013) recommended that in developing an invasive species eradication plan on an inhabited island, 'The local community must be engaged, involved in the planning process, and given a degree of ownership of the project'.

We feel that adequate tools and techniques for eradication or long-term management already exist. Improvements will undoubtedly be made to improve efficacy of the present methods. But trapping, baiting and shooting, in their various incarnations and combinations, are sufficient to effectively address invasive bird issues. Management of invasive species often represents a political or economic problem, not a scientific one. 'Invasive vertebrate species control or eradication has usually proved possible. Scientists have developed the methods; what is needed is the political will to use them' (Usher, 1989).

\subsection{Case Histories}

We have assembled information on global invasive bird species eradication attempts, separating those of founder populations from those well-established in their new environments in Tables 43.1 and 43.2. We have not included feasibility studies (e.g. control of Common Mynas on St Helena; Feare and Saavedra, 2009), ongoing control of invasive species limited to parts of their geographical range (e.g. Common Mynas in parts of Australia; Grarock et al., 2014) or field tests of potential control techniques (e.g. trials of Starlicide with free-living Common Mynas; Anon., 2009; Feare, 2010b). We define 'founder' populations as those of recent origin and which occupy a localized area within a larger area of potentially available habitat. 'Established' populations are those that have spread from the area of introduction to occupy a large area of available habitat, and which were introduced decades or centuries ago.

The range of species for which eradications have been undertaken is small (Tables 43.1 and 43.2), and many attempts at eradication have failed, especially in already established populations, but these failures have proved valuable in helping to identify techniques that are most promising for different species.

Table 43.1. Eradications of founder populations of invasive birds.

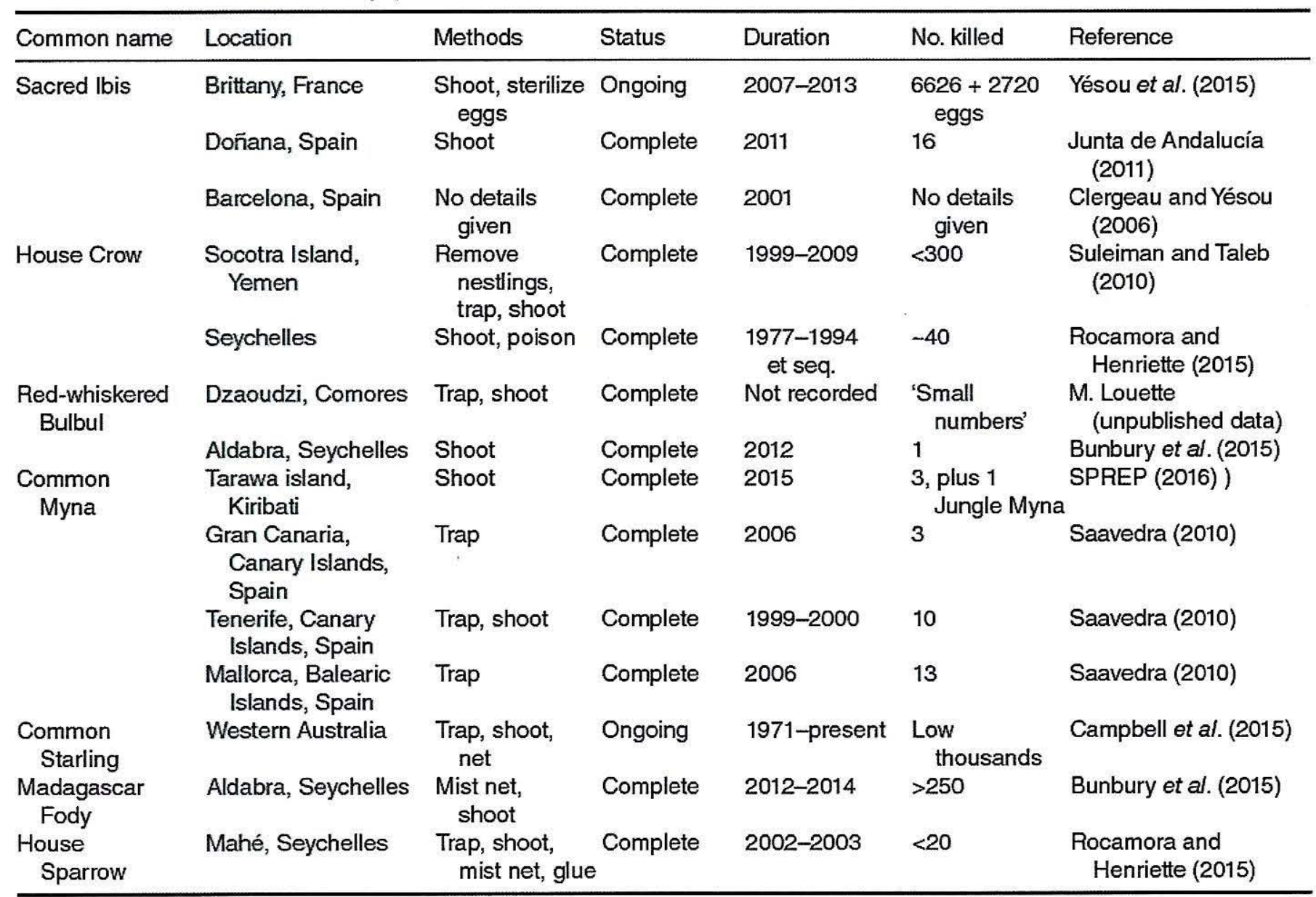


Table 43.2. Eradications of established populations of invasive birds.

\begin{tabular}{|c|c|c|c|c|c|c|}
\hline Species & Location & Methods & Status & Duration & No. killed & Reference(s) \\
\hline Wild Turkey & $\begin{array}{l}\text { Santa Cruz Island, } \\
\text { USA }\end{array}$ & $\begin{array}{l}\text { Trap, shoot, } \\
\text { 'Judas birds' }\end{array}$ & Complete & $2006-2012$ & $>310$ & $\begin{array}{l}\text { Morrison et al. } \\
\quad(2016)\end{array}$ \\
\hline Ruddy Duck & UK & Shoot & Ongoing & 1999-present & $>6800$ & Henderson (2010) \\
\hline \multirow[t]{3}{*}{ Rock Pigeon } & $\begin{array}{l}\text { Santa Cruz, } \\
\text { Galápagos Islands }\end{array}$ & $\begin{array}{l}\alpha \text {-Chloralose, shoot, } \\
\text { captives seized by } \\
\text { authorities }\end{array}$ & Complete & $2001-2007$ & 256 & Phillips et al. (2012) \\
\hline & $\begin{array}{l}\text { San Cristóbal, } \\
\text { Galápagos Islands }\end{array}$ & $\begin{array}{l}\text { Shoot, captives } \\
\text { seized }\end{array}$ & Complete & $2001-2007$ & 803 & Phillips et al. (2012) \\
\hline & $\begin{array}{l}\text { Isabela, Galápagos } \\
\text { Islands }\end{array}$ & $\begin{array}{l}\text { Shoot, captives } \\
\text { seized }\end{array}$ & Complete & $2001-2007$ & 418 & Phillips et al. (2012) \\
\hline $\begin{array}{c}\text { Ring-necked } \\
\text { Parakeet }\end{array}$ & Mahé, Seychelles & Shoot & Complete & $2013-2017^{a}$ & 548 & $\begin{array}{l}\text { Seychelles Island } \\
\text { Foundation (2018) }\end{array}$ \\
\hline $\begin{array}{l}\text { Red-whiskered } \\
\text { Bulbul }\end{array}$ & $\begin{array}{l}\text { Assumption Island, } \\
\text { Seychelles }\end{array}$ & Mist net, shoot & Complete & $2011-2014$ & $>5000$ & $\begin{array}{l}\text { Bunbury et al. } \\
\text { (2015) }\end{array}$ \\
\hline \multirow[t]{4}{*}{ Common Myna } & $\begin{array}{l}\text { Frégate Island, } \\
\text { Seychelles }\end{array}$ & $\begin{array}{l}\text { Trap, shoot, } \\
\text { nest trap }\end{array}$ & Complete & $\begin{array}{r}1993-2002 \\
2010-2011\end{array}$ & $>1460$ & $\begin{array}{l}\text { Millett et al. (2004); } \\
\text { Canning (2011) }\end{array}$ \\
\hline & $\begin{array}{r}\text { Denis Island, } \\
\text { Seychelles }\end{array}$ & $\begin{array}{l}\text { Starlicide, trap, } \\
\text { shoot }\end{array}$ & Complete & $\begin{array}{l}2010-2011 \\
2014-2015\end{array}$ & 1112 & $\begin{array}{l}\text { Millett et al. (2004); } \\
\text { Feare et al. } \\
\text { (2016) }\end{array}$ \\
\hline & North I, Seychelles & $\begin{array}{l}\text { Rodenticide } \\
\text { bycatch, Starlicide, } \\
\text { trap, shoot }\end{array}$ & $\begin{array}{l}\text { Nearly } \\
\text { complete }\end{array}$ & $\begin{array}{l}\text { 2005-2009, } \\
\text { 2012-present }\end{array}$ & $\begin{array}{c}>2630 \\
\text { (minimum } \\
3 \text { remain) }\end{array}$ & $\begin{array}{l}\text { Rocamora and } \\
\text { Henriette (2015); } \\
\text { C.J. Feare } \\
\text { (unpublished } \\
\text { data) }\end{array}$ \\
\hline & Atiu I, Cook Islands & Poison, trap, shoot & $\begin{array}{l}\text { Nearly } \\
\text { complete }\end{array}$ & $2009-2018^{a}$ & $>26,000$ & $\begin{array}{l}\text { G. McCormack } \\
\text { (unpublished } \\
\text { data) }\end{array}$ \\
\hline $\begin{array}{l}\text { Madagascar } \\
\text { Fody }\end{array}$ & $\begin{array}{l}\text { Assumption Island, } \\
\text { Seychelles }\end{array}$ & Mist net, shoot & Complete & $2011-2015$ & $>3000$ & $\begin{array}{l}\text { Bunbury et al. } \\
\text { (2015) }\end{array}$ \\
\hline House Sparrow & $\begin{array}{l}\text { Round Island, } \\
\text { Mauritius }\end{array}$ & $\begin{array}{l}\text { Trap, glue, shoot, } \\
\text { poison }\end{array}$ & Failed & 2008-2009 & $>300$ & $\begin{array}{l}\text { Bednarczuk et al. } \\
\text { (2010) }\end{array}$ \\
\hline
\end{tabular}

apost-eradication monitoring continuing.

\subsubsection{Founder populations}

Where prevention of incursions of invasive species has failed, the eradication of recently arrived individuals to prevent establishment in a new area must be a priority, as this opportunity represents the simplest and cheapest management option. This has been achieved in some instances where founder populations have been small or geographically localized (Table 43.1). Even here, however, eradication has not always been straightforward.

\section{Sacred Ibis}

In France, Sacred Ibis, imported to a zoo in Brittany, established a breeding colony from which the young could fly free (see Chapter 33, this volume). Some dispersed along the western seaboard of France, and breeding in the wild was first recorded in 1993. Subsequently, several breeding colonies have become established, totalling more than 1100 pairs by 2005 (Yésou and Clergeau, 2005), and sightings of Sacred Ibis more widely in Western Europe probably stem from these colonies. Concern over negative impacts on native wildlife prompted an eradication programme. During 2007-2013, 6626 birds were shot, and 2720 nests with eggs destroyed, leading to a population decline to 280-300 breeding pairs by 2013 (Yésou et al., 2015). In southern France, 395 adult Sacred Ibis and 90 chicks were removed from the natural environment during 2007-2013. By 2013, only three Sacred Ibis remained in Camargue (Fernandez, 2015).

In the USA, Sacred Ibis escaped from private collections and zoos following the devastating effects of Hurricane Andrew throughout South Florida in 1992 (see Chapter 33, this volume). Subsequently, numerous sightings of Sacred Ibis were reported in the region (Herring and Gawlik, 2008). The Everglades Cooperative Invasive Species Management Area, a partnership of several land management agencies, initiated the Sacred Ibis Project in 2007, and developed an EDRR plan to remove free-flying ibis from known locations and to respond efficiently to any new reports. Staff at the Zoo Miami livetrapped ibis by exploiting the birds' habituation to people and open-exhibit feeding practices. Zoo personnel captured ibis by baiting existing covered holding pens, erecting enclosures around feeding stations and orally administering sedation drugs. Each ibis trapped by Zoo Miami was surgically pinioned, 
measured, sexed and held for placement with other accredited facilities with a signed agreement acknowledging the invasive potential of the species and guaranteeing containment. Concurrently, the US Department of Agriculture Wildlife Services began killing birds by shooting on the zoo grounds and responded to reported sightings in nearby areas. Overall, 75 Sacred Ibis were removed from the wild ( 45 shot, 30 trapped) by the Wildlife Services and Zoo Miami staff during 2008-2011 (South Florida Ecosystem Task Force, 2015). The project prevented Sacred Ibis range expansions and successfully controlled the population while it remained localized.

\section{House Crow}

House Crow dispersal has been aided by ship-assisted travel along trading routes, leading to their establishment at ports around the Indian Ocean and on some of its islands (see Chapter 24, this volume). There have also been deliberate introductions in Africa, notably Zanzibar where the House Crow was released in the 1890 s, hoping that it would help clean up the town 'owing to its fondness for feeding on offal and refuse' (Vaughan, 1930).

In Yemen, a control programme on Socotra began in 1999 with unsuccessful attempts to live trap and to shoot crows. Schoolchildren were then encouraged to find crow nests and were paid for bringing in nests, young crows and adult birds to be humanely dispatched. During 2002-2007, 242 crows were removed. Finally, in 2008, expert marksmen were employed to shoot the remaining few adults (Suleiman and Taleb, 2010).

In the Seychelles, eradication of repeated small incursions of House Crows, some of which succeeded in breeding, was accomplished by the government's Environment Department, mainly by shooting (Rocamora and Henriette, 2015).

In Mauritius, Feare and Mungroo (1990) found that House Crows rapidly developed an aversion to bait treated with $\alpha$-chloralose following the removal of a small number of narcotized birds. Narcotization causes birds to behave abnormally, as might other toxicants (Feare, 2010b). In contrast, Puttoo and Archer (2004) reported that Starlicide applied to meat baits reduced their study population by almost $80 \%$ in a 12 -week control programme 'and could be safely used to control these birds in the future.' Previously, trapping had been ineffective, and shooting was deemed uneconomical and unsafe. We are not aware of any follow-up control efforts.

\section{House Sparrow}

In the Seychelles, a breeding population of ten to 20 House Sparrows was observed in the Port Victoria area on Mahé in 2002. Initial captures were made at feeding sites using mist nets, glue boards and feeding traps. Nest sites were identified at a power station, and a special trap was fitted over the nest-hole entrance, resulting in the capture of eight adults and two juveniles. After 11 months, just two sparrows remained, one of which was subsequently shot. The lone surviving male eventually died (Fanchette, 2003, as reported by Beaver and Mougal, 2009). Reinvasion via ship traffic is a continuing threat, so ongoing vigilance and reporting by port workers and the public is essential.

\section{Common Starling}

In Western Australia, trapping and shooting have predominated in the efforts to eradicate repeated incursions of Common Starlings (Woolnough et al., 2005; Campbell et al., 2015). Southern parts of the state have been periodically infiltrated by flocks of starlings, mainly from well-established populations in south-eastern states, from which Western Australia is separated by the arid and treeless Nullabor Plain. The Department of Agriculture of Western Australia has maintained a team of pest management practitioners and supported research in order to protect Western Australia's agriculture and environment from these incursions of potential founder populations, so far with success but at high cost (Woolnough et al., 2005; Rollins et al., 2009, 2011; Campbell et al., 2015).

\section{Common Myna}

In Spain, Saavedra (2010) demonstrated the efficacy of traps containing a live decoy in catching free-living birds, resulting in the eradication of three founder populations (Table 43.1).

In the port village of Betio, Kiribati, residents observed three Common Mynas and one Jungle Myna (Acridotheres fuscus) consistently in the vicinity. The presence of people and dogs in the area meant that toxic bait and live trapping would be unsuitable control methods. Shooting was deemed the most appropriate means of eradicating this small invasive population. Authorities brought in an experienced hunter from New Zealand who took care of the job in a couple of days. A number of factors contributed to the success of the project: (i) scouting of the area before the shooter arrived to learn the birds' activity patterns and to identify possible shooting locations; (ii) the assistance of local police to escort the shooter, manage site access and ensure public safety; (iii) an environment in which the mynas were accustomed to close encounters with people; and (iv) an experienced, committed hunter (SPREP, 2016).

\subsubsection{Established populations}

Many current invasive bird problems date back to the 19th century, when attempts were made to introduce birds, especially of European origin, to parts of the world that European people were colonizing (Low, 2001). Most introductions were for aesthetic reasons by acclimatization societies, but species such as the Common Myna were introduced because of anticipated pestcontrol benefits (Feare and Craig, 1998). Zoos and the pet trade contributed further to the international movement of animals, which resulted in the widespread establishment of non-native species in new environments. Some of these established populations have been targeted for eradication, with varying results. Eradications have concentrated on smaller populations, especially on small islands where the benefits of eradicating invasives can be particularly valuable for endangered wildlife.

\section{Common Myna}

By far the largest Common Myna eradication to date has been that on Atiu (2900 ha) in the Cook Islands, where over 26,000 
mynas are estimated to have been killed (G. McCormack, 2018, unpublished results). This complex project began as a control attempt, aimed at reducing the myna population initially by poisoning (Starlicide) and community trapping, using traditional chicken traps and supported by a bounty scheme. After 2 years, when the benefits of the reduced myna numbers became apparent to the island community in terms of reduced fruit damage and harassment of native birds, they decided to aim for total eradication and began shooting to augment the other control methods. Poisoning, estimated to have accounted for the deaths of approximately 11,500 birds, was stopped after 3.5 years when the reduced number of mynas no longer formed large feeding flocks that could be targeted, and shooting and trapping, now using decoy traps, became the techniques to finalize the eradication, accounting for 10,497 and 4768 (combined traditional and decoy trapping) birds, respectively. Since late 2015 , post-eradication vigilance has detected a further six mynas, of which four have been shot. These are believed to have been birds missed earlier, rather than new immigrants.

Attempts to achieve a rapid knock-down of numbers of Common Mynas, using the toxicant Starlicide, on Denis (143 ha) and North (201 ha) islands in the Seychelles, did not achieve the anticipated levels of kill that might have hastened the eradications, possibly due to the development of aversion to the treated bait and bait locations (Feare, 2010b, but see Avery and Eisemann, 2015, for discussion). However, these attempted knockdowns were not followed by determined use of additional measures to achieve eradication (Millett et al., 2004). On Frégate (219 ha) and Denis Islands, eradication was eventually achieved largely through trapping (Canning, 2011; Feare et al., 2016), as well as on North Island, with what is believed the last myna shot in February 2019 (Green Islands Foundation, Seychelles, 2019, personal communication).

Towards the end of the Common Myna trapping programmes in Seychelles, some individuals appeared to be 'trap shy'. It is unknown whether these individuals were wary of traps throughout the programmes or whether they learned to avoid them during the programme. On Frégate Island, Canning (2011) overcame this by resorting to different trap types at the end of the eradication, whereas on Denis and North Islands, marksmen with suitable firearms were employed to dispatch the final birds.

\section{Red-whiskered Bulbul and Madagascar Fody}

Following the successes of trapping Common Mynas in the Seychelles, trapping was considered as a useful technique for eradicating two other passerines that posed a threat to indigenous avifauna in these islands. In 1976-1977, Red-whiskered Bulbuls (Pycnonotus jocosus) and Madagascar Fodies (Foudia madagascariensis) were introduced to Assumption Island, Seychelles, which lies only $27 \mathrm{~km}$ from Aldabra Atoll, now a World Heritage Site managed by the Seychelles Island Foundation. Aldabra is relatively undisturbed by humans and supports a wide diversity of endemic and indigenous fauna and flora, including an endemic species of fody, Foudia aldabrana, and an endemic subspecies of bulbul, Hypsipetes madagascariensis rostratus, both of which were potentially threatened by the nearby presence of the introduced relatives. To avert the threat, eradication of these species was commenced in 2011. In contrast to their commensal behaviour elsewhere (Safford and Hawkins, 2013), early trials revealed that neither species on Assumption Island was attracted to artificially offered foods (e.g. rice, bread, fruits, dried mealworms, meat/fish) or to water in small ponds created for the birds. Nor were they attracted to broadcasts of conspecific calls or to decoy birds within cages. These attributes precluded trapping and were subsequently found to apply also to these invasive species on Aldabra Atoll. When roosting communally at night, however, it proved possible to catch commuting groups of birds in mist nets set across flight lines and this method became the main tool of the eradication programmes until low bird densities led to very low capture rates. At this stage, shooting became the final eradication technique for widely dispersed survivors, and eradication of both species was achieved (Bunbury et al., 2015).

\section{Ruddy Duck}

For some invasive bird eradications, shooting by competent marksmen has been the main tool. In the UK, introduced Ruddy Ducks (Oxyura jamaicensis) are being targeted in a government-led eradication (see Chapter 27, this volume). This is aimed at protecting the closely related endangered Whiteheaded Duck (Oxyura leucocephala) population of south-western Europe from genetic introgression (Hughes et al., 1999), as Ruddy Ducks have spread from the population originating in the UK through France and Spain, leading to limited hybridization with White-headed Ducks.

Ruddy Ducks are entirely aquatic, spending most of their time on the surface of freshwater bodies. Preliminary feasibility studies (Henderson, 2006) identified shooting, using shotguns and rifles, from boats to target flocks in winter and shooting from the bank at major breeding sites, targeting especially females to depress productivity, as the most promising eradication tactics (Henderson, 2009). Between 2005 and 2009, 95\% of the UK Ruddy Duck population was shot (Henderson, 2009, 2010). The estimated UK population at the end of the winter of 2017-2018 was approximately 23 birds, including at least five adult females. The birds were widely scattered across the UK and mixed-sex groups occurred in Northern Ireland, West and North London, and Greater Manchester and Cheshire. The last of these is of the most immediate concern, as north-west England is the only region where breeding seems to occur annually and was the only region where the birds bred in 2017 . There was no evidence of breeding anywhere in the UK during September 2018 (I. Henderson, personal communication).

This achievement was facilitated by the birds' concentration on a limited number of preferred water bodies for winter flocking and their continued use of these waters during and after shooting. Thus, a particular aspect of their behaviour rendered them vulnerable to the chosen eradication tactics.

\section{Wild Turkey}

From an initial introduction of seven birds in 1975, the Wild Turkey (Meleagris gallopavo) population on Santa Cruz Island, California, USA, grew to an estimated 310 in 2006. Fearing 
continued growth of the turkey population with consequent elevated threats to native biota, managers initiated a removal programme. Investigators exploited the tendency of turkeys to flock in the winter and devised an integrated management approach using baited drop nets, precision shooting and monitoring of surgically sterilized, radio-telemetered 'Judas turkeys'. By October 2007, the only turkeys remaining were several of the 'Judas turkeys', which were monitored until the last one died in 2012 (Morrison et al., 2016).

\section{Ring-necked Parakeet}

Ring-necked Parakeets (Psittacula krameri) are the most widely kept and traded parrot species, and have escaped from captivity, or been released, in many countries (see Chapter 9, this volume). They are widely seen as competitors for nest sites with native hole-nesting species (Strubbe and Matthysen, 2009), including the congeneric Echo Parakeet (Psittacula eques) of Mauritius (Mauritian Wildlife Foundation, 2018) and the Seychelles Black Parrot (Coracopsis barklyi), restricted to Praslin Island (Reuleaux et al., 2013) and now recognized as a species endemic to the Seychelles (Jackson et al., 2015). The latter was considered to be vulnerable to nest site competition from Ring-necked Parakeets that had established a large feral population on Mahé, and of which one individual had appeared on Praslin and Silhouette Islands (Bunbury et al., 2015). To mitigate this risk to the Black Parrot, the Seychelles Island Foundation initiated an eradication programme for the Ring-necked Parakeet in 2013. Most of the parakeets on Mahé roosted in clumps of bamboo in the south-east of the island, but control there was deemed unwise as it risked breaking up the roost into satellite roosts all over the island, some of which might be inaccessible. Various control tactics were explored (e.g. high-level mist netting), but shooting birds at feeding sites by marksmen proved to be the most successful eradication tool. Potential shooting sites were identified by the Seychelles Island Foundation staff and through media appeals to the public, supported by a bounty payment for notifications that led to the shooting of a parakeet. What is believed to have been the last bird was shot in August 2017. Monitoring of reports of further birds, still supported by the bounty scheme, is continuing to verify the eradication. Up to September 2018, no further parakeets have been discovered (Seychelles Island Foundation, 2018).

\section{Monk Parakeet}

In the USA, free-flying Monk Parakeets (Myiopsitta monachus) were first reported from the New York/New Jersey metropolitan area in 1967, and nest construction was observed in 1970. These earliest populations in the New York/New Jersey area probably originated from escaped cage birds. The Monk Parakeet was first recorded as breeding in Florida in 1969 (Owre, 1973) and has been resident there ever since. In Connecticut, Monk Parakeets were first recorded in 1971 (Neidermyer and Hickey, 1977). Import records reveal that during 1968-1972, more than 63,000 Monk Parakeets were imported into the USA from South America, mostly from Paraguay (CITES, 2018).

Concerns over possible agricultural damage, transmission of psittacosis and interspecific competition with native wildlife precipitated a nationwide Monk Parakeet retrieval programme coordinated by the US Fish and Wildlife Service (Neidermyer and Hickey, 1977). During 1970-1975, there were 367 confirmed sightings of Monk Parakeets in 30 states, and 163 birds were removed from 16 states, mostly from New York (88) and California (35). The 163 birds removed represented $44 \%$ of the estimated population at that time, and authorities considered the programme a success in reducing the growth and spread of Monk Parakeet populations (Neidermyer and Hickey, 1977). Since 1975, there has been no coordinated, large-scale Monk Parakeet control effort, and the species is currently firmly established in several states of the USA.

Several lessons can be taken from this experience:

1. Biosecurity was lax, and thousands of birds were imported before official permitting was established. Even after a Federal permitting process was in place, thousands more were imported until the practice was prohibited in the early 1990s.

2. EDRR was non-existent. Through the commercial cagebird trade, Monk Parakeets were imported and spread around the country for years with no management response. The single management response that was organized (Neidermyer and Hickey, 1977) was insufficient, and there was no follow-up.

3 . There was little strong public opposition to the one nationwide eradication effort during 1970-1975. Currently, Monk Parakeets are fiercely defended whenever and wherever any management actions are proposed. A prime opportunity for eradication was clearly missed.

\section{Rock Pigeon}

Rock Pigeons (Columba livia) were first recorded in the Galápagos Islands in the early 1970 s, and by 2000 , the total population had grown to over 600 birds on three islands: Santa Cruz, San Cristóbal and Isabela (Phillips et al., 2012). To eliminate the potential of pigeons transmitting diseases to humans and native wildlife, authorities opted to implement a pre-emptive eradication programme. The integrated management approach included toxic baiting with $\alpha$-chloralose (only on Santa Cruz), shooting and confiscation of captive pigeons. The programme ended in 2007 after 1477 Rock Pigeons had been removed, and the species was formally declared eradicated from the Galápagos Islands. Phillips et al. (2012) noted several factors that contributed to the success of the programme: (i) the pigeon populations were dependent on humans and occurred in accessible, confined areas; (ii) the pigeons' flocking and feeding behaviour combined with lack of wariness made them very vulnerable to shooting; (iii) a diverse set of methods was not needed because the shooting programme was implemented safely and efficiently, and it proved to be highly effective; and (iv) much of the field work was conducted by reliable local residents who were integrated into and trusted by the communities.

\section{House Sparrow}

On Mauritius, a variety of techniques were used in an attempt to eradicate House Sparrows from Round Island to pave the way for introducing some of Mauritius's endangered endemic 
birds (Bednarczuk et al., 2010). During the attempt, however, it became apparent that Round Island's House Sparrow population was not closed and that immigration from other nearby islands occurred, causing the eradication attempt to be curtailed.

\subsection{Duration and Cost}

The samples on which to base the estimated duration and costs of eradications are small, and few data are available on the latter. Furthermore, post-eradication vigilance, involving ongoing costs, is essential to confirm that eradication has been completed and to detect any new arrivals, especially important on archipelagos where other populations of the invasive species exist.

In general, Tables 43.1 and 43.2 show that eradication of founder populations takes considerably less time than eradication of established populations. The apparent exception is the eradication of founder populations of Common Starlings in Western Australia, which requires ongoing vigilance over a large area and the repeated eradication of incursions as they are discovered.

The successful eradications of established populations of invasive birds have all been multi-year projects, involving a number of staff. On Denis and North Islands, in the Seychelles, costs have been saved by using volunteers to undertake most of the trapping, but unexpected resignations or illness of volunteers, and difficulties of recruitment of new staff at the end of short-term (often 6-month) contracts, prolonged the eradications (Feare et al., 2016; C.J. Feare et al., unpublished data). Canning (2011), a permanent member of staff on Frégate Island, on the other hand, took only 8 months to eradicate Common Mynas. The eradications of Red-whiskered Bulbuls and Madagascar Fodies on Assumption Island, and that of Ring-necked Parakeets on Mahé, Seychelles, were completed in less than 5 years using dedicated staff. This suggests that the Denis and North Islands myna eradications could have been achieved over shorter time scales. Whether the eradication of Common Mynas on Atiu, in the Cook Islands, could have been completed in less than the 9 years taken so far is doubtful, given the large sizes of the island, much of it forested, and of the myna population. This also applies to the Ruddy Duck eradication in UK, where, despite the dedicated team of practitioners, the birds' wide geographical distribution, open-water habitats and difficulties of access to some waters have all led to a prolonged eradication process.

Campbell et al. (2015) estimated that the annual expenditure on vigilance and control of Common Starling founder populations entering the southern regions of Western Australia, of approximately AUS $\$ 1.2$ million (approximately US\$ 864,000 ) up to 2009 (dropping to AUS $\$ 600,000$ thereafter following budget cuts) was economically justified in view of the potential annual economic damage inflicted on Western Australian agriculture of AUS $\$ 42.8$ million (US $\$ 30.8$ million) by the estimated carrying capacity of starlings in Western Australia. This damage estimate referred only to agricultural produce and did not include ecosystem or human social costs. Campbell et al. (2015) anticipated that expenditure on technological developments in the detection and management of starlings would provide further economic benefits.
For established populations, Feare et al. (2016) estimated that the overall cost of the eradication of Common Mynas on Denis Island, Seychelles, was approximately US $\$ 156,950$. The cost of the much larger myna eradication on Atiu, Cook Islands, has been estimated at around NZ\$270,000 (US\$178,200) (G. McCormack, unpublished data).

Cost estimates of further eradications of invasive birds, currently in progress or nearing completion, are needed to assist in the planning of future eradication attempts, and the lessons learned from all eradication attempts will hopefully increase operational efficiency and reduce costs in the future.

\subsection{Conclusions}

Successful eradications of invasive bird populations, although much fewer than for invasive mammals, have taken place mostly on islands. Demonstration of successful eradications could increase the call for more such operations. Avian eradications were carried out using various combinations of shooting, toxic baiting and trapping. In almost every case, the justification for eradication was protection of native biota. Careful, thorough, up-front planning was essential for every effective eradication programme. Coordination with and integration of local populace and authorities was vital to the planning and implementation of eradication efforts. It is doubtful that eradication of invasive bird populations on a continent-wide basis is feasible. Long-term management of established mainland populations might be a more realistic option, given the constraints of cost and public opinion.

In two of the case histories we described, authors invoked the Precautionary Principle as justification for proceeding with eradication programmes. As stated by Rogers et al. (1997) 'the Principle requires action to prevent serious and irreversible damage even before harm can be scientifically demonstrated or economically assessed'. This principle was applied to eradication of Rock Pigeons in the Galápagos out of concern for disease and health risks (Phillips et al. 2012), and also in eradication of Wild Turkeys from Santa Cruz Island, USA, to eliminate a prey base for a top-level predator (Morrison et al., 2016). This principle was also applied to House Sparrow invasions in the Lesser Antilles (Clergeau et al. 2004). Simberloff (2003) expressed a similar point of view, arguing that an immediate management response to invasive species is more effective than spending the time and resources to study the problem while the invader proliferates, spreads and becomes increasingly more difficult and expensive to eradicate. Managers might be uncomfortable acting without complete knowledge of the impacts and costs of an invasive species, but broader application of the Precautionary Principle is worth consideration.

\subsection{Acknowledgements}

We are grateful to Gerald McCormack for providing us with the latest information on the eradication of Common Mynas on Atiu, Cook Islands. Michael Moulton shared unique insights into invasive bird biology and facilitated access to many original information sources. 


\subsection{References}

Agoramoorthy, G. and Hsu, M.J. (2007) Ritual releasing of wild animals threatens island ecology. Human Ecology 35, 251-254.

Anon. (2009) Myna eradication programme. DRC1339 trial report. Terrestrial Resources Conservation Section, Division of Environment and Conservation, Samor.

Avery, M.L. and Eisemann, J.D. (2015) Invasive myna control in American Samoa. Vertebrate Pest Conference 26, $140-144$.

American Veterinary Medical Association (2001) 2000 report of the AVMA panel on euthanasia. Fournal of the American Veterinary Medical Association 218 , $669-696$.

Beaver, K. and Mougal, J. (eds) (2009) Review of IAS control and eradication programmes in Seychelles. Plant Conservation Action Group. Available at: www. pcaseychelles.org/uploads/1/2/3/6/12369400/seychelles_ias_control-erad_review_pca_report_only.pdf (accessed 12 November 2019).

Bednarczuk, E., Feare, C.J., Lovibond, S., Tatayah, V. and Jones, C.G. (2010) Attempted eradication of house sparrows Passer domesticus from Round Island (Mauritius), Indian Ocean. Conservation Evidence 7, 75-86.

Bennett, F.D. and Hughes, I.W. (1959) Biological control of insect pests in Bermuda. Bulletin of Entomological Research 50, 423-436.

Blackburn, T.M., Lockwood, J.L. and Cassey, P. (2009) Avian Invasions. Oxford University Press, New York.

Bomford, M. and O'Brien, P. (1995) Eradication or control for vertebrate pests? Wildlife Saciety Bulletin 23, 249-255.

Bunbury, N., Moumou, J., Page, N., Feare, C., Crommenacker, J., et al. (2015) The eradication of introduced red-whiskered bulbuls and Madagascar fodies from Assumption and Aldabra. In: Rocamora, G. and Henriette, E. (eds) Invasive Alien Species in Seychelles. Biotope, Mèze, France, and Muséum National d'Histoire Naturelle, Paris.

Campbell, S., Roberts, E.J., Craemer, R., Pacioni, C., Rollins, L. and Woolnough, A.P. (2015) Assessing the economic benefits of starling detection and control to Western Australia. Australasian fournal of Environmental Management 23, 81-99.

Campbell, K. and Donlan, C.J. (2005) Feral goat eradications on islands. Conservation Biology 19, 1362-1374.

Canning, G. (2011) Eradication of the invasive common myna, Acridotheres tristis, from Frégate Island, Seychelles. Phelsuma 19, 43-53.

Cardador, L., Lattuada, M., Strubbe, D., Tella, J.L., Reino, L., et al. (2017) Regional bans on wild-bird trade modify invasion risks at a global scale. Conservation Letters 10,717-725.

CITES (2018) CITES trade database. Available at: https://trade.cites.org/ (accessed 25 September 2018).

Clergeau, P. and Yésou, P. (2006) Behavioural flexibility and numerous potential sources of introduction for the sacred ibis: causes of concern in western Europe? Biotogical Invasions 8, 1381-1388.

Clergeau, P., Levesque, A. and Lorvelec, O. (2004) The precautionary principle and biological invasion: the case of the House Sparrow on the Lesser Antilles. International Fournal of Pest Management 50, 83-89.

Cooney, R. and Jepson, P. (2006) The international wild bird trade: what's wrong with blanket bans? Oryx 40, 18-23.

DeCino, T.J., Cunningham, D.J. and Schafer, E.W. (1966) Toxicity of DRC-1339 to starlings. Zournal of Wildlife Management 30, $249-253$.

Department of Primary Industries (2010) Invasive plants and animals policy framework. State of Victoria, Australia. Available at: http://agriculture.vic.goviau/ agriculture/pests-diseases-and-weeds/protecting-victoria-from-pest-animals-and-weeds/invasive-plants-and-animals/invasive-plants-and-animalspolicy-framework (accessed 2 October 2018).

Dunlap, T.R. (1997) Remaking the land: the acclimatization movement and Anglo ideas of Nature. Fournal of World History 8, 303-319.

Eisemann, J.D., Pipas, P.A. and Cummings, J.L. (2003) Acute and chronic toxicity of compound DRC-1339 (3-chloro-4-methylaniline hydrochloride) to birds. In: Linz, G.M. (ed.) Management of North American Blackbirds. USDA APHIS National Wildlife Research Center, Fort Collins, Colorado, pp. 49-63.

Fanchette, R. (2003) Successful eradication of an IAS from Mahe island, Seychelles (House Sparrow Passer domesticus) 2002-2003. Unpublished report by the Government of Seychelles.

Feare, C. and Craig, A. (1998) Starlings and Mynas. Christopher Helm, London.

Feare, C.J. (2010a) Invasive bird eradication from tropical oceanic islands. Aliens 30, 12-19.

Feare, C.J. (2010b) The use of Starlicide in preliminary trials to control invasive common myna Acridotheres tristis populations on St Helena and Ascension islands, Atlantic Ocean. Conservation Evidence 7, 52-61.

Feare, C.J. and Mungroo, Y. (1990) The status and management of the house crow Corvus splendens in Mauritius. Biological Conservation 51, 63-70.

Feare, C.J. and Saavedra, S. (2009) Development of a strategy for control of common mynas (Acridotheres tristis) on St Helena. Unpublished report to the Royal Society for the Protection of Birds and the South Atlantic Invasive Species Project.

Feare, C.J., van der Woude, J., Greenwell, P., Edwards, H.A., Taylor, J.A., et al. (2016) Eradication of common mynas Acridotheres tristis from Denis Island, Seychelles. Pest Management Science 73, 295-304.

Fenneman, J. (2011) Checklist of the Birds of British Columbia. LGL Limited Environmental Research Associates, Sidney, British Columbia, Canada. Available at: http://ibis.geog.ubc.ca/biodiversity/efauna/documents/BCBirdChecklistJan2011.pdf (accessed 17 September 2018).

Fernandez, S. (2015) Eradicating the sacred ibis around the Mediterranean basin. In: Sarat, E., Mazaubert, E., Dutartre, A., Poulet, N. and Soubeyran, Y. (eds) Invasive alien species in aquatic environments. Practical information and management insights. Vol. 2: Management Insights. Knowledge for Action Series, ONEMA. Vincennes, France, pp. 189-195. Available at: www.gt-ibma.eu/wp-content/uploads/2017/08/eee-vol-2-complet-12-10-16-1.pdf (accessed 2 October 2018).

Fleming, P.J.S., Ballard, G., Reid, N.C.H. and Tracey, J.P. (2017) Invasive species and their impacts on agri-ecosystems: issues and solutions for restoring ecosystem processes. Rangeland fournal 39, 523-535.

Glahn, J.F. and Avery, M.L. (2001) Estimation of red-winged blackbird mortality from toxic bait application. In: Johnston, J.J. (ed.) Pesticides and Wildlife. American Chemical Society Symposium Series 771. American Chemical Society, Washington, DC, pp. 109-118.

Glen, A.S., Atkinson, R., Campbell, KJ., Hagen, E., Holmes, N.D., et al. (2013) Eradicating multiple invasive species on inhabited islands: the next big step in island restoration? Biological Invasions 15, 2589-2603.

Grarock, K., Tidemann, C.R., Wood, J.T. and Lindenmayer, D.B. (2014) Understanding basic species population dynamics for effective control: a case study on community-led culling of the common myna (Acridotheres tristis). Biological Invasions 16, 1427-1440.

Harvey, R.G. and Mazzotti, F.L. (2014) The invasion curve: a tool for understanding invasive species management in south Florida. IFAS Extension Report WEC347, Wildlife Ecology and Conservation Department, University of Florida, Florida. Available at: https://edis.ifas.ufl.edu/uw392 (accessed 12 November 2018). 
Henderson, I. (2010) The eradication of ruddy ducks in the United Kingdom. Aliens Nensletter 29, 17-24.

Henderson, I.S. (2006) Recent measures to control ruddy ducks Oxyura jamaicensis in the United Kingdom. In: Boere, G.C., Galbraith, C.A. and Stroud, D.A. (eds) Waterbirds around the World. The Stationery Office, Edinburgh, UK, pp. 822-825.

Henderson, I.S. (2009) Progress of the UK ruddy duck eradication programme. British Birds 102, 680-690.

Herring, G. and Gawlik, D.E. (2008) Potential for successful population establishment of the non-indigenous sacred ibis in the Florida Everglades. Biological Invasions $10,969-976$.

Hobson, E.A., Smith-Vidaurre, G. and Salinas-Melgoza, A. (2017) History of nonnative monk parakeets in Mexica. PLoS One 12, e0184771.

Howald, G., Donlan, C., Galván, J.P., Russell, J.C., Parkes, J., et al. (2007) Invasive rodent eradication on islands. Conservation Biology 21, $1258-1268$.

Hughes, B., Criado, J., Delany, S., Gallo-Orsi, U., Green, A.J., et al. (1999) The status of the North American ruddy duck Oxyura jamaicensis. In: The Western Palearctic: Tomards an Action Plan for Eradication, 1999-2002. Council of EuropePublication T-PVS/Birds (99) 9. Council of Europe Publishing, Strasbourg, France.

Jackson, H.A., Bunbury, N., Przelomska, N. and Groombridge, J.J. (2015) Evolutionary distinctiveness and historical decline in genetic diversity in the Seychelles black parrot Coracopsis nigra barklyi. Ibis 158, 380-394.

Junta de Andalucía (2011) Control del ibis sagrado africano en Andalucía. Boletin Informative Sobre Geodiversidad de Andalucia, 18, 1-2. Available at: www.juntadeandalucia.es/medioambiente/portal_web/web/servicios/centro_de_documentacion_y_biblioteca/fondo_editorial_digital/revistas_boletines/geobio/ numero_18/ibis_sagrado_ampliada.pdf (accessed 12 November 2019).

Kurdila, J. (1995) The introduction of exotic species into the United States: there goes the neighborhood. Environmental Affairs 16, 95-118.

Lever, C. (2005) Naturalized Birds of the World. T. \& A.D. Poyser, London.

Low, T. (2001) Feral Future. Penguin Books, Ringwood, Victoria, Australia.

Martin-Albarracin, V.L., Amico, G.C., Simberloff, D. and Nuñez, M.A. (2015) Impact of non-native birds on native ecosystems: a global analysis. PLoS One 10, e0143070.

Mauritian Wildlife Foundation (2018) Echo parakeet Psittacula eques. Available at: www mauritian-wildlife.org/projects (accessed 12 November 2018).

McDowall, R.M. (1994) Gamekeepers for the Nation: The Story of New Zealand's Acclimatisation Societies 1861-1990. Canterbury University Press, Christchurch, New Zealand.

Millett, J., Climo, G. and Jivan Shah, N. (2004) Eradication of the common myna Acridotheres tristis populations in the granitic Seychelles: successes, failures and lessons learned. Advances in Vertebrate Pest Management 3, 169-183.

Morrison, S.A., DeNicola, A.J., Walker, K., Dewey, D., Laughrin, L., et al. (2016) An irruption interrupted: eradication of wild turkeys Meleagris gallopavo from Santa Cruz Island, California. Oryx 50,121-127.

Neidermyer, W.J. and Hickey, J.J. (1977) The monk parakeet in the United States, 1970-1975. American Birds 31, $273-278$.

Owre, O.T. (1973) A consideration of the exotic avifauna of southeastern Florida. Wilson Bulletin 85, 491-500.

Parkes, J. (2012) Review of best practice management of common mynas (Acridotheres tristis) with case studies of previous attempts at eradication and control: a working document. Contract Report LC986, prepared for Durrell Wildlife Conservation Trust, Landcare Research, Lincoln, New Zealand.

Phillips, R.B., Cooke, B.D., Carrión, V. and Snell, H.L. (2012) Eradication of rock pigeons, Columba livia, from the Galápagos Islands. Biological Conservation 147, 264-269.

Pimentel, D., McNair, S., Janecka, J., Wightman, J., Simmonds, C., et at. (2001) Economic and environmental threats of alien plant, animal, and microbe invasions. Agricuiture, Ecosystems and Environment 84, 1-20.

Puttoo, M. and Archer, T. (2004) Control and/or eradication of Indian crows (Corvus splendens) in Mauritius. In: Lalouette, J.A. and Bachraz, D.Y. (eds) Proceedings of the Sixth Meeting of Agricultural Scientists. Food and Agricultural Research Council, Réduit, Mauritius, pp. 299-309.

Reuleaux, A., Bunbury, N., Villard, P. and Waltert, M. (2013) Status, distribution and recommendations for monitoring of the Seychelles black parrot Coracopsis (nigra) barklyi. Oryx 47, 561-568.

Robinson, S.A. and Copson, G.R. (2014) Eradication of cats (Felis catus) from subantarctic Macquarie Island. Ecological Management and Restoration 15, $34-40$.

Rocamora, G. and Henriette, E. (2015) Invasive Alien Species in Seychelles. Biotope, Mèze, France, and Muséum National d'Histoire Naturelle, Paris.

Rogers, M.F., Sinden, J.A. and De Lacy, T. (1997) The precautionary principle for environmental management: a defensive-expenditure application. Fournal of Environmental Management 51, 343-360.

Rollins, L.A., Woolnough, A.P., Sinclair, R., Mooney, N.J. and Sherwin, W.B. (2011) Mitochondrial DNA offers unique insights into invasion history of the common starling. Molecular Ecology 20, 2307-2317.

Rollins, L.A., Woolnough, A.P., Wilton, A.N., Sinclair, R. and Sherwin, W.B. (2009) Invasive species can't cover their tracks: using microsatellites to assist management of starling (Sturnus vulgaris) populations in Western Australia. Molecular Ecology 18, 1560-1573.

Ryan, C.S. (1906) President's address: on European and other birds liberated in Victoria. Emu 5, 110-119.

Saavedra, S. (2010) Eradication of invasive mynas from islands. Is it possible? Aliens 29, 40-47.

Safford, R. and Hawkins, F. (2013) The Birds of Africa, Vol. 8: The Malagasy Region. Christopher Helm, London.

Seychelles Island Foundation (2018) Seychelles Island Foundation Newsletter, Issue 68, August 2018. Available at: www.sif.sc/sites/default/files/downloads/ SIF\%20Newsletter\%20AUGUST\%202018_0.pdf (accessed 13 September 2018).

Simberloff, D. (2003) How much information on population biology is needed to manage introduced species? Conservation Biology 17, 83-92.

Simberloff, D. (2009) We can eliminate invasions or live with them; successful management projects. Biological Invasions 11, $149-157$.

South Florida Ecosystem Task Force (2015) EDRR case study: the sacred ibis project. Available at: https://evergladesrestoration.gov/content/ies/docs/Goal2 Case_Study_Sacred_Ibis.pdf (accessed 29 September 2018).

SPREP (2016) Manage myna birds in the Pacific. Secretariat of the Pacific Regional Environment Programme (SPREP), Apia, Samoa.

Strubbe, D. and Matthysen, E. (2009) Experimental evidence for nest-site competition between invasive ring-necked parakeets (Psittacula krameri) and native nuthatches (Sitta europaea). Biological Conservation 142, 1588-1594.

Suleiman, A.S. and Taleb, N. (2010) Eradication of the house crow Corvus splendens on Socotra, Yemen. Sandgrouse 32, $136-140$.

Temple, S.A. (1992) Exotic birds: a growing problem with no easy solution. Auk 109, 395-397.

Thomson, G.M. (1922) The Naturalisation of Animals and Plants in Nem Zealand. Cambridge University Press, Cambridge.

Tidemann, C.R. (2005) Indian mynas - can the problems be controlled? National Urban Animal Management Conference 15, 55-57. 
Tsachalidis, E., Sokos, C., Birtsas, P. and Patsikas, N. (2006) The Australian crow trap and the Larsen trap: their capture success in Greece. In: Manolas, E.I. (ed.) Proceedings of the 2006 Naxos International Conference on Sustainable Management and Development of Mountainous and Island Areas, Vol. II. Department of Forestry and Management of the Environment and Natural Resources, Democritus University of Thrace, Komotini, Greece, pp. 325-329.

Usher, M.B. (1989) Ecological effects of controlling invasive terrestrial vertebrates. In: Drake, J.A., Mooney, J.A., di Castri, H.A., Groves, F., Kruger, R.H., et al. (eds) Biological Invasions: A Global Perspective. Wiley, Chichester, UK, pp. 463-489.

Vaughan, J.H. (1930) The birds of Zanzibar and Pemba, part II. Ibis 72, 1-48.

West, B. and Zhou, B.-X. (2007) Did chickens go north? New evidence for domestication. World's Poultry Science foumal 45, $205-218$.

Woolnough, A.P., Massam, M.C., Payne, R.L. and Pickles, G.S. (2005) Out on the border: keeping starlings out of Western Australia. Australasian Vertebrate Pest Conference 13, 183-189.

Yésou, P. and Clergeau, P. (2005) Sacred ibis: a new invasive species in Europe. Birding World 18, 517-526.

Yésou, P., Maillard, J.-F. and Simon, L. (2015) Managing the sacred ibis in western France. In: Sarat, E., Mazaubert, E., Dutartre, A., Poulet, N. and Soubeyran, Y. (eds) Invasive Alien Species in Aquatic Environments. Practical Information and Management Insights. Vol. 2: Management Insights. Knowledge for Action Series, ONEMA, Vincennes, France, pp. 196-199. Available at: www.gt-ibma.eu/wp-content/uploads/2017/08/ece-vol-2-complet-12-10-16-1.pdf (accessed 2 October 2018). 